\title{
The Effects of Integrated Drama-Based Role Play and Student Teams Achievement Division (STAD) on Students' Speaking Skills and Affective Involvement
}

\author{
Lawarn Sirisrimangkorn, Jitpanat Suwanthep \\ Suranaree University of Technology, Thailand
}

\begin{abstract}
The study investigates the pedagogical use of integrated drama-based role play and Student Teams Achievement Division (STAD) cooperative learning, and its effects on the first year non-English majors' speaking skills, motivation, and self-esteem. The study was conducted over an academic semester in a basic English class in a northeastern university in Thailand with two separate groups, with a quasi-experimental design. The participants in this study were 80 non-native undergraduate students whose major was not English. Over the 16 weeks of the study, both groups of students studied English with the same learning content; however, only the experimental group was introduced to drama-based role play and STAD, with blended-learning instruction, while the control group continued using the course book role plays with regular group work activities and classroom instruction. Both quantitative (t-test) and qualitative (content analysis) methods were used to analyze the results of the study. The results of the quantitative and qualitative analysis showed the effectiveness of drama-based role play combined with STAD on students' speaking skills, motivation, and self-esteem in the experimental group. The study concludes with recommendations for the integration of the blended drama-based and cooperative learning to improve students' English speaking skills and affective involvement.
\end{abstract}

Suranaree University of Technology, Thailand

\section{Introduction}

Teaching language through drama has such potential because it gives a context for listening and meaningful language production, in which learners need to use their language resources (Chauhan 2004). Drama pedagogy provides authentic communicative environments for the learners, and drama activities can be used 
to heighten learners' speaking ability (Ulas 2008; Janudom \& Wasanasomsithi 2009). In addition, the implementation of drama pedagogy benefits learners' motivation and self-esteem through its non-threatening classroom environments (Donnery 2009; Pacyga 2009; Read 2009). A classroom with drama activities motivates learners to learn and provides them with a relaxing yet challenging environment in which to study. Drama-based role play is an activity in which students develop a story together. In doing this, they are required to engage in the preparation of a role play and act it out (Cockett 2000). Drama-based role play has positive effects on learners' communicative and affective skills as it stimulates the learners' authentic conversation and allows them to act in a framework, so they can overcome their fear of certain emotional, linguistic or social constraints (Brash et al. 2009). When learners learn English through drama, they learn not only language use, but also communicative processes. Drama-based activities focusing on meaningful language, interactive communication, and cooperative group work can stimulate participation (Dailey 2009). With regard to cooperative learning, cooperative learning activities are also often used in language teaching. Cooperative learning is an instructional approach which encourages students' learning through group interaction. It provides maximum opportunities for meaningful input and output in interactive and supportive environments (Ghaith 2003).

STAD (Student Teams Achievement Division) is an instructional cooperative approach with a focus on small groups of learners with divergent abilities working together to reach a shared learning goal. English speaking skills are increasingly important for EFL learners; however, many Thai learners have very low English speaking skills (Pattaranon 1988; Jong-Utsah 1988, cited in Janudom \& Wasanasomsithi 2009). Moreover, Thai undergraduate students are not confident in either speaking or listening to the target language even though communicative language teaching has been implemented (Sukanake, Heaton, Chantrupanth \& Rorex 2003). Generally, graduate students should have adequate English speaking skills so that they can communicate effectively in English. For this reason, it is necessary to find e ffective pedagogical techniques to help develop students' speaking skills while improving their affective involvement. The use of drama activities can fulfill a spects of the development of learners' English skills in the second or foreign language classroom. Several researchers (Royka 2002; Zyoud 2007) point to the benefits of drama such as bringing enjoyment to lessons and increasing students' positive learning experiences. Nevertheless, Gaudart (1990) claims that drama pedagogy is an extremely time-consuming approach. Even though drama is fun, for many traditional teachers it is not a serious method for learning (Royka 2002). Furthermore, Belz (2002, cited in Swenddal 2011) echoes the concerns on language learning through drama activities (language play) and notes that it is viewed as a superfluous a ctivity that deviates from a 'serious' process of language learning. Despite all the criticism of the use of drama in a language classroom, Swenddal (2011) claims that learners will derive benefits from drama engagement as their language acquisition processes are stimulated and 
supported.

In view of the concerns over drama practices in language play, this study investigates an appropriate approach, which may be integrated with dramabased role play in order for students to practice communicative activities and become affectively involved. In this light, STAD can be integrated into the drama-based role play as it may provide benefits for language learners, including opportunities for interaction with other students which can lead to communication among them, at the same time enhancing the students' motivation and self-esteem. Certain STAD components can be applied to create structured environments of drama-based role play procedures. These include: class presentations, which call for students' individual participation in the task; working in teams, which requires students' group cooperation; and the use of quizzes, which test students' attention to learning content and task completion. Making use of these components can make learners' engagement and interaction in drama-based role play more meaningful and purposeful. In the classroom, drama-based role play and STAD may support an authentic and non-threatening learning environment which encourages the exchange of knowledge between the students. Drama brings enjoyment to learners, motivates them to learn and increases their self-esteem. In learning English, learners can play with language through drama-based activities, while they follow the components of STAD which keep them focused on learning processes at all time. Therefore, STAD may be used with drama-based activities as it encourages students who are used to the traditional system to get involved in communicative language learning. Learning procedures under STAD may be an effective tool for learners to efficiently learn with drama-based role play. This is why the researchers would like to outline useful pedagogies that best suit the language skills essential to students' successful performance of drama activities. Thus, the present study aims to answer the following research questions:

1. How does the integration of drama-based role play and STAD affect students' speaking skills?

2. How does the integration of drama-based role play and STAD affect students' motivation and self-esteem?

This study on integrated drama-based role play and STAD is expected to yield more insights into the combination of drama pedagogy and cooperative language learning, which may lay the foundation for applications in other EFL teaching contexts.

\section{Background}

Nakhon Ratchasima Rajabhat University (NRRU) is a local university in Nakhon Ratchasima, Thailand. NRRU provides various bachelor courses for undergraduate students. The English Foundation course is one of the compulsory 
subjects and it requires learners to successfully develop communicative skills and basic English knowledge for usage in both inside and outside of the classroom. The English Foundation class at NRRU consists of three periods (150 minutes) which are offered once a week and each English Foundation class consists of students with different levels of English proficiency. According to Noom-Ura (2008: 175), a classroom of divergent students requires a particular teaching method that focuses on a variety of activities "with the hope that either one or other of the activities will help the majority of students to some extent, while slow learners become temporarily 'invisible' or ignored." Generally, NRRU undergraduate students have studied English for at least 12 years; however, many of them have low English proficiency, especially in oral output. In Thailand, speaking skills are a critical part of language learning and teaching process; however, it may be extremely difficult for Thai learners to master the English language in terms of communicative skills (Khamkhien 2010) due to low motivation and self-esteem, as they are reluctant to participate in communication activities in the language class. The two main reasons for this may arise from the lack of an English-speaking environment and an interactive learning atmosphere. Many students in other EFL countries have many opportunities to encounter and use English; however, Thai students have few chances to use English as they tend be exposed only to Thai media and instruction. English is rarely used in public or even in a classroom. This may also cause Thai students' negative feelings towards English. Moreover, Wiriyachitra (2004) state that Thai students face difficulties in learning English because they are mostly passive learners and too shy to use the language to communicate in class. Furthermore, Piatanyakorn (2003, cited in Grubbs et al. 2008) found that Rajabhat students' English proficiency level was affected either directly or indirectly by their background, the time spent learning English, the teachers, and the classroom tools. This laid the foundation for the rationale of using drama-based role play and STAD to improve the learning situation. The adoption of drama-based activities aims to stimulate students to be active learners and to form a communicative and cooperative learning environment.

\section{Drama Pedagogy and Cooperative Learning}

The quasi-experimental research design was conducted with two groups of students who received different treatment and instructions. Drama-based role play and STAD were designed and implemented with the experimental group of students, while the control group used the course book role play and group work. The effects of the integration were determined by comparing the scores of the pre- and post-speaking tests, Attitude and Motivation Battery Test (AMBT), and Self-Esteem Test (SET) of the participants. Semi-structured interviews and students' journals were used to investigate students' perceptions towards the tasks conducted in the experimental group. 


\subsection{Drama-based role play}

In this study, the drama-based role play activities had of six components: (1) drama-based role play scaffolding, (2) script co-creation, (3) group rehearsal, (4) performance recording, (5) performance presentation, and (6) reflection. The details of each phrase are as follows:

1. Drama-based role play scaffolding: students are provided with a video clip based on the theme of each unit. This video clip functions as scaffolding for the students.

2. Script co-creation: students are required to create a conversation or script relevant to the content of the unit they have studied. The script should be developed by all group members.

3. Rehearsal: The students rehearse their performance based on their script. They can rehearse independently as many times as they want before recording their actual performance.

4. Performance recording: The students record their performance.

5. Performance presentation: The students' performance is presented the class so that teacher and peers can evaluate and share ideas based on the assignment.

6. Reflection: Classmates are encouraged to reflect on each group's performance. The comments obtained should be taken into consideration in order to improve the next group's performance.

Drama-based role play allows participants to create and develop their roles independently. Language learners are required to engage in the preparation of the role play and then act it out. Likewise, students in this study are required to record six drama-based videos based on six role-play situations. The important aspect of working on this kind of role play is the fact that students converse together. In terms of authentic communication, "drama-based role play can lessen the feeling of artificiality of the $l$ anguage $\mathrm{c}$ lassroom a nd $\mathrm{m}$ ay make learning more realistic and meaningful" (Brash et al. 2009: 102).

\subsection{Student Teams Achievement Division (STAD)}

Individual accountability means students' individual responsibility for their own learning, which can result in team success. It is seen as an important factor in the success of drama-based activities. Teams cannot be successful without individual accountability between the members. It starts with each learner having individual accountability for their own learning in the class presentations provided through e-learning lessons. Then, learners apply and contribute their knowledge through in-class group work and assignments. 
While working in groups, they share their experiences, test their knowledge, and produce output together. For a result, they demonstrate learning products to their peers and reveal the significance of those experiences together. STAD is composed of five components: (1) class presentations; (2) work in teams; (3) quizzes; (4) individual improvement scores; and (5) team recognition. Each component is integrated in order to promote students' English learning through drama-based role play. As for the first component, the 'class presentations' are based on students' learning on the content provided by the teacher. The students are required to approach the content through e-learning before actual classroom instruction. The second component, the 'team' component, encourages students to learn and work cooperatively with their classmates. During the process, the students work in teams based on team assignments and co-creation scripts. 'Quizzes' make up the third component, focusing on the individual accountability of each student. They are supposed to perform better in each quiz so that they earn improvement scores for their team. The fourth component, 'individual improvement scores', encourages the students to make an effort and develop their own learning. Each learner's improvement scores can contribute to their team performance. Finally, 'team recognition', the last component, urges all members in each team to work together in order to get the team reward.

\section{Data Analysis}

\subsection{Quantitative results}

Speaking skills - In terms of speaking, there was a statistically significant difference in the post-speaking test at .01 level between the two groups. The mean scores of the experimental group (Mean $=29.95$, S.D. $=2.096$ ) was higher than that of the control group (Mean $=23.10$, S.D. $=3.393$ ), respectively (see Table 1). The results of post- speaking tests highlighted that students in the experimental group had statistically higher post-test scores than students in the control group.

Table 1: Speaking Skills

\begin{tabular}{|l|l|l|l|l|l|}
\hline Test & Group & N & Mean & S.D & Sig.(2-tailed) \\
\hline \multirow{2}{*}{ Pre-test } & Experimental & 40 & 22.08 & 2.324 & .534 \\
& Control & 40 & 21.58 & 2.701 & \\
\hline \multirow{2}{*}{ Post-łest } & Experimental & 40 & 29.95 & 2.096 & .000 \\
& Control & 40 & 23.10 & 3.393 & \\
\hline
\end{tabular}


Motivation - For motivation, there was a statistically significant difference in the post-AMBT at .01 level between the two groups. The post-AMBT mean scores of the experimental group (Mean $=91.25$, S.D. $=4.634$ ) was higher than that of the control group (Mean $=85.43$, S.D. $=5.546$ ), respectively (see Table 2). The results of AMBT highlighted that students in the experimental group had statistically higher motivation than students in the control group.

Table 2: Motivation

\begin{tabular}{|l|l|l|l|l|l|}
\hline Test & Group & $\mathrm{N}$ & Mean & S.D & Sig.(2-tailed) \\
\hline Pre-test & Experimental & 40 & 74.25 & 4.813 & .390 \\
& Control & 40 & 75.15 & 4.498 & \\
\hline \multirow{2}{*}{ Post-test } & Experimental & 40 & 91.25 & 4.634 & .000 \\
& Control & 40 & 85.43 & 5.546 & \\
\hline
\end{tabular}

Self-Esteem - With regard to self-esteem, there was a statistically significant difference in the post-SET at .01 level between the two groups. The postSET mean scores of the experimental group $(x=66.00$, S.D. $=7.449)$ was significantly higher than that of the control group ( $x=56.45$, S.D. $=6.341$ ), respectively. The results of the post-SET highlighted that students in the experimental group had statistically higher self-esteem than students in the control group (see Table 3). Such findings show that instruction based on drama-based role play and STAD is likely to develop speaking skills, motivation, and affective involvement.

Table 3: Self-Esteem

\begin{tabular}{|l|l|l|l|l|l|}
\hline Test & Group & $\mathrm{N}$ & Mean & S.D & Sig.(2-tailed) \\
\hline Pre-test & Experimental & 40 & 53.23 & 9.781 & .716 \\
& Control & & 52.43 & 9.834 & \\
\hline Post-test & Experimental & 40 & 66.00 & 7.449 & .000 \\
& Control & & 56.45 & 6.341 & \\
\hline
\end{tabular}

\subsection{Qualitative results}

As far as the qualitative results are concerned, data was collected through interviews and students' reflections in their journals. To interpret the qualitative 
results, content analysis was conducted in this study. It started with the overview of all learner responses to each question, which were then grouped into certain specific areas. Semi-structured interviews were conducted after the completion of the integrated drama-based role play and STAD activities at the end of semester. The students of the experimental group were interviewed in order to collect their perceptions of the integration of drama-based role play and STAD. In terms of speaking, students were asked whether the tasks helped them to develop their speaking skills. The students agreed that drama activities had a positive effect on their speaking skills. The reasons given are as follows: firstly, $40 \%$ of students reported that drama activities provided them with chances to practice speaking. Most students claimed that they were afforded more opportunities to use what they had learned from the class in a practical way. This is interesting because English is a compulsory subject in Thailand. The students have to study English from grade one. Outside the classroom, there are few chances for them to use English. Examples of their translated responses are reported below:

"I was hardly exposed to English when I was in high school, but activities in this class provided me with chances to utilize what I had learned in a practical way."

'Previously, I had few chances to use English. I often spoke 'Yes', 'No', 'OK', but when we were assigned to work on the assignment, I got a chance to use English."

Secondly, $30 \%$ of students reported that the activities encouraged them to use English authentically, for example:

"Drama-based activities help me to use English in a real situation. Not only theory that we study, but we also use English in a practical way. Drama-based instruction is efficient. To explain this, when we study one subject, if we study only theory, it is theory that we know. Then, we lack of self-confidence. Drama-based activities help us to be successful in learning."

Finally, 30\% of students explained that they developed their speaking skills as they became familiar with the speaking tasks of the drama activities.

"I think it helps me improve English speaking. Previously we didn't practice much English. However, when we are assigned to record video in English, we are more familiarized and dare to think, speak, and do activities in English."

In terms of motivation, most students confirmed that $\mathrm{d}$ rama-based activities helped them develop their motivation due their interesting design and the enjoyable instruction. For self-esteem, most students indicated that the activities helped increase their self-esteem because they were involved in the activities at all times and felt that their contributions mattered. As for reflections specifically 
related to the effects of STAD elements on their English learning, most students reported that each component of STAD helped them develop their English skills and kept them involved in the English class. Students saw the first component of STAD, which is based on e-learning, as an important channel for reviewing English. Secondly, students said that the team component was beneficial a s it e ncouraged them to w ork a nd c ooperatively s olve problems with peers. Next, quizzes were useful as students were encouraged to be active in their learning and provided them with feedback. The fourth component helped develop students' English learning. The increasing improvement scores motivated students to pay more attention in class. For the last component, the students mostly pointed to the benefit of the component as a reward for them. They were not serious about being the winning team, but they felt good if they were rewarded. To summarize, the results obtained showed that the integrated drama-based role play and STAD were beneficial to students' learning.

In terms of the disadvantages of the integration of drama-based role play and cooperative learning, one student pointed out that the learning procedures were complicated, especially the first t ime. Moreover, there were many things to complete for this class, considering the fact that they also had other activities to do for other classes. They had limited time and it took a while to get used to the learning procedures. However, the student was sure that if he had another chance to work on drama-based role play in future courses, he would understand all tasks and learn more easily.

The students also gave suggestions for the study: they suggested the use of drama-based activities in other English classes. Results from students' journals were similar to those from the interviews. The results obtained showed that students viewed integrated drama-based activities as beneficial to their speaking proficiency, motivation and s elf-esteem. In terms of their speaking proficiency, they agreed that the improvement in their speaking was a result of three drama-based activities: script writing, individual speaking practice and group rehearsal. While they co-created the script, they were reminded how to speak English appropriately and correctly. After that, individual speaking practice was included as it helped them to be ready to converse with their interlocutors. Finally, they thought that the group rehearsal helped them communicate appropriately. Most students claimed they benefitted from the cooperation among peers as they completed the assignments. It can be seen that principles of drama pedagogy and cooperative learning support each other. Drama pedagogy and cooperative learning encourage learners to get involved in activities at all times. Cooperation supports them in working and helping each other. This is why cooperative learning can be successfully implemented into drama-based activities.

Drawing from the findings o ft he s tudy, i t c ould b e c oncluded that the integration of drama-based role play and STAD was effective for the improvement of speaking skills, motivation and self-esteem. In terms of the quantitative analysis, there were statistically significant differences in the post-speaking tests, AMBT, and SET between two groups of students. The 
mean scores highlighted that students benefited from the integration of drama pedagogy and cooperative learning. As regards qualitative analysis, students' perceptions towards the activities provided further support for the effectiveness of the proposal.

\section{Benefits}

\subsection{Speaking Skills Development}

The results obtained showed that students' experiences in working on the integrated drama-based and STAD tasks helped them develop their speaking skills. Engaging in drama-based activities kept students involved in their language development, especially when creating the script for their teams. When students worked on the script, they produced utterances and utilized linguistic knowledge that they previously learned. At the same time, they discussed the structure and usage of English that should be implemented in each dialogue. Each group was required to introduce the learning content into their dialogues, which were based on suggested situations, so the dialogue might be as simple as those which they had previously learned, or more creative. Moreover, students were encouraged to look for sets for the recordings and use props in order to make their video more interesting. They had to brainstorm and discuss various components of their recordings. Talking about structures, vocabulary, sets, and props encouraged them to increase their language skills (vocabulary and fluency). These activities led students to communicate with a purpose. They also gained benefits in nonverbal language from working on drama-based role plays through rehearsals: they learned how to express themselves nonverbally and use more body language in various situations so as to enact different roles in different situations. As with other drama-based activities, students were expected not only to develop language skills, but other non-linguistic abilities, such as movement. As Dodson (2002) notes, paralinguistic elements like body language, gestures and proxemics (use of individual physical space) are as important to communicating as grammar. Engaging in drama-based activities supports both verbal and nonverbal communication.

\subsection{Classroom Benefits}

The obtained data showed that students' classroomlearning skills had developed. According to the principles of cooperative learning, students are expected to help each other to learn and complete the assignment, and so students worked cooperatively on writing scripts and recording their performance based on the scripts. As a result, the students learned to listen to each other, which is important for cooperative learning. Even though there was one main writer in each group, students learned to listen to each other's comments. Discussion skills were also promoted among peers while working in group on the drama-based assignment as students were required to discuss what to do 
and how to do it. The assignment helped students to function in terms of (1) promoting group working skills; and (2) building personal relationships. With regard to the results of student interviews and journals, students perceived the integration of drama-based role play and STAD as beneficial for classroom learning as they encouraged them to expand on what they had studied in appropriate ways in an appropriate environment. Moreover, students were encouraged to become more aware of each other's needs. As one student claimed, the first time they studied cooperatively, some peers just sat there and did nothing for the team, but when they knew that they had to do quizzes and improve team scores, it made them become more active learners. The poor performance of the other teammates was not a problem when working in a cooperative learning environment but if some students refused to join in at all, the overall team performance would be lower. Cooperative learning requires individual contribution from each group member. It is acceptable if some group members cannot perform as well as others. Divergent ability of students is not a problem as STAD encourages students to motivate each other to perform better. "If students value doing well as a group, and the group can succeed only by ensuring that all group members have learned the material, then group members will be motivated to teach each other." (Slavin 1995: 42)

\subsection{Personal Benefits}

According to the research results, the affective involvement of the participants improved in terms of motivation and self-esteem. Even though Thai learners study English from grade one, many of them have negative feelings towards the language and low affective involvement. One reason behind their negative attitude may arise from the lack of opportunity to be exposed to English both inside and outside the classroom. Lack of practice may decrease students' interest and confidence in the u se of $\mathrm{E}$ nglish. In this s tudy, s tudents were required to create dialogues by themselves, and rehearsed and recorded their performances outside the classroom. The integrated drama-based role play and STAD was seen as a communicative task that helped support learning environments that were interactive and non-threatening and encouraged students to work cooperatively. These might be the reason for their positive affective involvement after finishing the course. In terms of motivation, students commented that they thought their motivation had increased through the task. Interestingly, one student said that "I'm surprised when I can answer English questions. I want to practice more so that I will be a better English learner." Many students also pointed to the usefulness of the drama-based role play for their future use of English. One student claimed that "I can teach other children by using my knowledge. It is beneficial for daily life and future career." These comments show that the activities led to heightened student motivation as they reported that they would like to use English more both inside and outside of the classroom. There are some studies that also confirm the effects of drama pedagogy on students' motivation (Miccoli 2003; Guadart 1990). It 
was found that students' self-confidence in their learning ability also increased, as shown by the statistical analysis and confirmed by results from students' interviews. One student said that "If I pay much attention, I can understand English." The use of drama provides a focus and support for learners to use language in an independent way and also contributes to building up their confidence a nd s elf-esteem ( Read 2 009). W hen the s tudents h ave positive affective involvement, they feel freer to participate and communicate. The task helped them in terms of both empathy and communication. Interestingly, many students also profited in terms of the content of study, as they felt encouraged to learn more. For example, one student said that "I have learned more about the famous person whom I selected to talk about for the assignment. English makes me know more about the related topic."

The combination of drama pedagogy and cooperative learning can motivate students to learn English with a positive attitude and have fun with language learning. Even though students were given situations to create scripts for, they still had the freedom to select the topic for themselves. This safety zone allowed them to creatively imagine and design the activities in accord with their team members. As a result, the students developed creativeness and imagination as shown by various set selections and props chosen for their drama production. As McCaslin (1996) claims, drama provides an opportunity for independent thinking. And curriculum planners can benefit $\mathrm{f}$ rom the integration of drama-based activities and cooperative learning strategies in communication courses for EFL learners.

\section{Recommendations}

Based on a variety of classroom activities derived from the integration of dramabased role play and STAD, this study provides a rationale for the inclusion of such activities in different types of classrooms. The study also offers a strong argument for the introduction of learner-centered tasks into traditional English classroom instruction, thus promoting a plausible and alternative pedagogy to teacher-centered classrooms. Moreover, these classroom activities might be beneficial in enhancing students' active participation in class. The activities also lead students to develop not only speaking skills but also other skills that are important for the learners, such as discussion skills and writing skills. Based on cooperation, it fosters students' working spirit and personal relationships, while the individual accountability ensures the responsibility of each student to work on the drama-based role play assignments. This study has shown the potential of such a combination approach to encourage students to devote themselves to team assignments. It seems that drama pedagogy and cooperative learning are well matched because the components of cooperative learning can support drama-based activities. 


\section{Conclusions}

Many Thai undergraduate EFL learners face difficulties in communicating in English even though they have studied English for many years. Their ineffective communication skills are often due to affective factors. For non-English majors, who lack opportunities to use English in their daily lives, positive perceptions of English and eagerness to learn may help them to learn more by themselves in the long run. One possible reason behind learners' lack of effective communicative skills may result from their unstable feelings or low affective involvement. The lack of flexible environment may be one factor influencing students' perceptions towards English. In this study, the students were allowed to work in cooperative groups so they could learn from each others' previous experiences and mistakes. Group cooperation appeared to strengthen their cooperative skills and the cooperative skills strengthened each individual learner in turn. Also, students learned that mistakes were acceptable. Drama-based activities provided them with opportunities to study flexibly and improve their language proficiency. As a result, they perceived that English was not as difficult as they had thought: they realised that there were a great many activities they could carry out easily and successfully.

\section{Bibliography}

Belz, Julie (2002): Second Language Play as a Representation of the Multicompetent Self in Foreign Language Study. In: Journal of Language, Identity \& Education 1, 13-39

Brash, Bärbel; Warnecke, Sylvia (2009): Shedding the ego: drama-based role-play and identity in distance language tuition. In: Language Learning Journal 37 (1), 99-109

Chauhan, Vani (2004): Drama techniques for teaching English. In: The Internet TESL Journal, 10(10).

(http://iteslj.org/Techniques/Chauhan-Drama.html)

Cockett, Stephen (2000): Role-play in the post- 16 language class. A drama teacher's perspective. In: Language Learning Journal 22, 17-22

Dailey, Michael (2009): Acting out: A one-year drama class to increase participation. In: The Language Teacher, 33(2).

(http://jalt-publications.org/tlt/articles/452-acting-out-oneyear-drama-class-increase-participation)

Dodson, Sarah L. (2002): The Educational Potential of Drama for ESL. In: Brauer, G. (Ed.): Body and Language: Intercultural Learning Through Drama. Westport, CT: Ablex Publishing, 161-179

Donnery, Eucharia (2009): Testing the Waters. Drama in the Japanese University EFL Classroom. In: Scenario 1, 1-19

Gaudart, Hyacinth (1990): Using Drama Techniques in Language Teaching. In: Sarinee, Anivan (ed.): Language Teaching Methodology for the Nineties. 
Anthology Series 24. Singapore: Southeast Asian Ministers of Education Organization. Rationale Language Center, 230-245

Ghaith, Ghazi (2003): Effects of the Learning Together model of cooperative learning on English as a foreign language reading achievement, academic achievement, academic self-esteem, and feelings of school alienation. In: Bilingual Research Journal, 27 (3), 451- 474

Grubbs, Samuel J.; Chaengploy, Salisa; Worawong, Kanoknate (2008): Rajabhat and traditional universities: institutional differences in Thai students' perceptions of English. In: Higher Education, 5 (1), 283-298

Janudom, Ratchadaporn; Wasanasomsithi, Punchalee (2009): Drama and questioning techniques: Powerful tools for the enhancement of students' speaking abilities and positive attitudes towards EFL learning. In: ESP World, 8(5), 23-28

Khamkhien, Attapol (2010): Teaching English Speaking and English Speaking Tests in the Thai Context: A Reflection from Thai Perspective. In: English Language Teaching, 3 (1), 184-190

McCaslin, Nellie (1996): Creative Drama in the Classroom and Beyond. London. Longman Publishers

Miccoli, Laura (2003): English through drama for oral skills development. In: ELT Journal, 57(2), 122-129

Noom-ura, Sripathum (2008): Teaching listening-speaking skills to Thai students with low English proficiency. In: Asian EFL Journal, 10 (4), 173-192

Pacyga, Jonell (2009): Affecting L2 Attitude and Motivation Through Drama. M.A. Dissertation. Hamline University, St. Paul, MN

Piatanyakorn, Sikan (2003): A study of the casual relationship model with reference to variables affecting English achievement of educational students in North-Eastern Rajabhat Institutes. In: Sakon Nakhon Graduate Studies Journal 1 (1), 47-54

Read, Carol (2008). Scaffolding children's learning through story and drama. IATEFL Young Learner Publication, 2008-2. (http: //www.countryschool.com/ylsig/members/articles/CAT_Autumn08.pdf)

Royka, Judith Gray (2002): Overcoming the fear of using drama in English language teaching. In: The Internet TESL Journal, 8 (6) (http://iteslj.org/articles/Royka-Drama.html)

Slavin, Robert E. (1995): Cooperative Learning: Theory, research, and practice. ( $2^{\text {nd }}$ ed.) Boston, MA: Allyn \& Bacon

Sukanake, Rathawan; Heaton, Suzanne Leslie; Chantrupanth, Dhanan; Rorex, Paul Dale (2003): Thai university EFL learners' oral responses to various spoken question types. In: Studies in Second Language Learning and Teaching, 12, 19-32.

Swenddal, Heather (2011): How drama facilitates language learning. A case for using drama in the second-language classroom. (http://heatherswenddal.myefolio.com/portfolio/papers/) 
Lawarn Sirisrimangkorn, Jitpanat Suwanthep

Suranaree University of Technology, Thailand

The Effects of Integrated Drama-Based Role Play and Student

Teams Achievement Division (STAD) on Students' Speaking

Skills and Affective Involvement

Scenario

Volume $2013 \cdot$ Issue 2

Ulas, Abdulhak H. (2008): Effects of Creative, Educational Drama Activities on Developing Oral Skills in Primary School Children. In: American Journal of Applied Sciences 5, 876-880

Wiriyachitra, Arunee (2004): English language teaching and learning in Thailand in this decade. In: Thai TESOL Focus, 15(1), 4-9.

Zyoud, Munther (2010): Using Drama Activities and Techniques to Foster Teaching English as a Foreign Language: a Theoretical Perspective. (Conference presentation, TEFL Methods \& Practices at Palestinian Universities)

(http://www.qou.edu/english/conferences/firstNationalConference/pdfFiles/muntherZyoud.pdf) 